\title{
Endocrine disruptors and ovine reproductive development
}

\author{
Richard G. Lea ${ }^{1,2}$, Andrew S. Byers ${ }^{1,2}$, Michelle Bellingham ${ }^{3}$, \\ Corinne Cotinot ${ }^{4}$, Neil Evans ${ }^{3}$, Beatrice Mandon-Pepin ${ }^{2}$, Kevin D. Sinclair ${ }^{1}$, \\ Paul A. Fowler ${ }^{5}$ \\ ${ }^{1}$ Schools of Veterinary Medicine and Biosciences, University of Nottingham, Sutton Bonington \\ Campus, Loughborough LE12 5RD; ${ }^{2}$ School of Animal, Rural and Environmental Sciences, Nottingham \\ Trent University, Brackenhurst Campus, Southwell, NG25 OQF; Institute of Biodiversity, Animal \\ Health and Comparative Medicine, College of Medical, Veterinary and Life Sciences, University of \\ Glasgow G61 1QH; " INRA, UMR 1198, Biologie du Développement et Reproduction F-78350, Jouy- \\ en-Josas, France; ${ }^{5}$ Division of Applied Medicine, Institute of Medical Sciences, University of Aberdeen, \\ Foresterhill, Aberdeen AB25 2ZD
}

\begin{abstract}
Summary
Declining fertility and perturbations in reproductive development in a variety of species have been linked to exposure to endocrine disrupting chemicals (EDCs), which are ubiquitous in the environment. Ruminants are largely exposed to such chemicals in sewage sludge fertiliser widely used in animal production systems. This has been investigated experimentally through the deliberate exposure of pregnant ewes to sewage sludge fertilised pastures or control pastures treated with inorganic fertiliser containing no detectable EDCs. Perturbations in the developing fetal hypothalamic-pituitary-gonadal axis have been observed in both male and female fetuses. A sub-population of rams exposed both pre- and post-natally exhibited adversely altered testis development. Periods of developmental sensitivity to EDCs have also been identified. An in vitro culture system for ovine fetal ovaries has shown that mixtures have a greater effect than individual chemicals. The dog provides a sentinel model of human dietary exposure to chemicals in ruminant-derived food products. Evidence of altered fertility and testicular cancer, along with EDC detection in dog testes and pet foods, support this concept. Established rodent models of EDC exposure provide a means to investigate mechanisms and transgenerational effects. Overall, monitoring and in vitro studies carried out in sentinel species and on human tissues, combined with in vivo mechanistic studies carried out in ruminants and rodents, provides a clear picture of the global impact of EDCs on reproductive development. In particular, the ovine model of sewage sludge exposure provides the only currently available "real life" model of exposure to a cocktail of EDCs.
\end{abstract}

\section{Introduction}

Since the publication of Silent Spring in 1962, perturbations in reproductive development in a variety of species have been increasingly associated with exposure to anthropogenic environmental chemicals (Carson 1962). The periods of fetal and early post-natal development are particularly sensitive to such exposures and this reflects the exquisite control of fetal 
organogenesis mediated by endocrine, metabolic and other key biological signalling processes. The term "endocrine disrupting chemicals (EDCs)" is frequently used to describe those chemicals which interfere with the endocrine system, however it is now clear that many of these chemicals perturb a wide range of other biological processes and physiological systems including gametogenesis, steroidogenesis, the neuroendocrine and immune systems as well as nutrient partitioning and metabolism. Since all of these processes are crucial for reproductive development, EDCs have the potential to impact on fertility at multiple levels.

\section{Exposure to environmental chemicals}

Chemicals described as EDCs are extremely heterogeneous and originate from a diverse range of sources including plastics, industrial lubricants and solvents, detergents, adhesives, pesticides, cosmetics, fertilisers and even analgesic pharmaceuticals. The main route of exposure to EDCs is through the diet (including by drinking), however less characterised modes of exposure also occur through the inhalation of industrial volatile organic chemicals, the production of which has markedly increased in recent years, and by absorption through the skin (Rhind et al. 2010). Ruminants are exposed to EDCs largely through modern day domestic animal production systems, reflecting the replacement of costly inorganic fertilisers with processed human sewage sludge (reviewed in Rhind et al. 2010). Sewage sludge contains a cocktail of thousands of environmental chemicals, thus constituting a major source of exposure that may be higher (i.e. accumulating over time) than found in the environment (Rhind et al. 2013). Exposure largely occurs through the ingestion of soil and to a lesser extent herbage, and this level of exposure has been described as relevant to "real life". Indeed a controlled sewage sludge experimental model has been characterised as a model for human exposure as described in detail below. Ruminants will also be exposed to pollutants through air inhalation although the level of such contamination has not been characterised.

This review is designed (1) to update current understanding on the impact of EDCs on ruminant reproductive development and production and (2) to discuss the relevance of data obtained from ruminant studies to other species, including humans. The relative advantages and disadvantages of alternative animal models will be reviewed and the ruminant work placed into perspective in relation to the global problem of environmental contamination with EDCs.

\section{Ruminants and endocrine disruptors}

An experimental ovine model of exposure to a mixture of EDCs was developed by exposing ewes to pastures to which sewage sludge had been applied. Although a variety of pollutants have been detected in sewage sludge, its application had minimal short-term effects on soil chemical concentrations when compared to control pastures fertilised with inorganic fertiliser (Rhind et al. 2002, Stevens et al. 2003). Similarly, liver concentrations in ewes grazing the pastures showed only slight changes compared to controls (Rhind et al. 2005, 2009). Despite these minor effects of sewage sludge exposure on maternal and fetal liver concentrations, the exposure of pregnant ewes from conception to euthanasia at mid or late gestation, or the continued exposure of the offspring to weaning, markedly perturbs the development of all organs of both the male and female reproductive axes (see below).

Similarly, EDCs have been detected in bovine tissues at low concentrations and are derived from contaminated pastures (Petro et al. 2010). Given the low levels of EDCs in sheep purposely exposed to sewage sludge and showing clear effects on reproduction, chemical measurements 
alone (frequently at only one end-point) do not preclude an environmental impact on ruminant fertility and reproduction. It is of note that polychlorinated biphenyls (PCBs) in milk are elevated in high-producing dairy cows compared to lower yield dairy cows (Petro et al. 2010). This reflects the negative energy balance and associated lipolysis that characterises high milk yield cows and is thus a potential source of exposure for the human consumer. Organochlorine pesticides and PCBs have been detected in bovine and ovine semen and human studies indicate that poor sperm quality may be associated with direct exposure to environmental contaminants (Rozati et al. 2002, Kamarianos et al. 2003b, Zhang et al. 2006). In examining bull fertility in a limited geographic region, a strong statistically significant correlation between the levels of pesticide used and the number of spermatozoa in semen was found (Snoj et al. 2013). Overall these data indicate that the multifactorial problem of declining fertility in the dairy cow is likely to include one or more environmental components.

\section{Effects on the male}

In the human male, exposure to EDCs has been associated with increasing incidences of testicular cancer, congenital abnormalities at birth (cryptorchidism, hypospadias) and a decline in sperm counts in adulthood. Since these problems cluster in specific geographical areas, they probably have a similar aetiology and are collectively referred to as testicular dysgenesis syndrome (TDS) (Skakkebaek et al. 2001). The rapid period of time over which this has occurred is indicative of an environmental, rather than principally genetic, cause and there is a vast literature based upon a variety of animal models. Although the decline in sperm counts has received the most publicity, it is also the most controversial. Historically, interest in declining human sperm quality stems from a meta-analysis of studies looking at sperm counts published in 1992 (Carlsen et al. 1992). Carlsen reported a decline in human sperm counts between 1938 and 1990 and this was further corroborated by the addition of 47 more studies and re-analysis in 2000 (Swan et al. 2000). A number of additional studies have been published, the most notable being that of Rolland et al. showing a decline in semen quality across France between 1989 and 2005 (Rolland et al. 2013). Nevertheless, these findings have been criticised on the basis of inconsistencies in andrology methods and changes in laboratory quality assurance during the period of analysis (Pacey 2013). More recent studies have cast further doubt on the precise nature of the changes in sperm counts, suggesting a modest reversal (Jorgensen et al. 2012). However, they nevertheless show that a worryingly large proportion of young men have below optimal sperm quality. In contrast, studies showing an increased incidence of human male congenital abnormalities at birth (especially in small for gestational age neonates) and testicular cancer are more robust and widely accepted (Jackson et al. 1986, Bergstrom et al. 1996). A large proportion of genital abnormalities have been reported in rams examined in UK abattoirs (Smith et al. 2012), including hypospadias, and these may reflect exposure to EDCs. There is also evidence of a decline in bull semen quality between 1970 and 1985, although post 1985, a number of sperm parameters improved while sperm morphology declined (Wahl \& Reif 2009). The variability may reflect potential methodological inconsistencies as suggested for the human. An additional confounder in such studies is the culling of sub-fertile animals which may account for the lack of such a trend in an earlier study (Setchell 1997, Karoui et al. 2011).

The sewage sludge model of EDC exposure has been used to investigate the impact of a cocktail of environmental chemicals on testis development. The exposure of pregnant ewes to sewage sludge fertilised pastures from conception to day 110 of gestation reduced both the number of Sertoli cells and Leydig cells in the fetal testis and the hormones produced by 
these cell types: inhibin A and testosterone respectively (Paul et al. 2005). The perturbation of Sertoli cell function has serious implications for adult male fertility. Sertoli cells are critical for germ cell development and, subsequently, sperm production. Consequently, perturbed Sertoli cell proliferation and/or differentiation will impact on spermatogenesis in adult life. Recently, the period of sewage sludge exposure was extended to include exposure via the mother from conception and the post-natal period until weaning (Bellingham et al. 2012), thus ensuring that all periods of Sertoli cell proliferation and development were included (Fig. 1). Five of 12 exposed rams were shown to exhibit significant testicular abnormalities manifest by fewer germ cells, calculated per testis or Sertoli cell, and increased numbers of tubules that only contained Sertoli cells. While these data support the concept that the germ cell is a key target for EDCs (Lagos-Cabre \& Moreno 2012), it is uncertain why only a subset of animals appears to be susceptible to EDC exposure. Nevertheless, this finding is more similar to human than rodent studies and factors including differences in grazing or ingestion patterns or differences in maternal and/or fetal metabolism may be responsible. With respect to the latter, polymorphisms in metabolic genes have been reported in humans, e.g. GSTP1, GSTM1 genes and these may modulate polycyclic aromatic hydrocarbon-DNA adducts (PAH-DNA) in human mononuclear white blood cells (Butkiewicz et al. 2000). Although sperm counts were unaffected in the 12 rams, repeated ejaculations were not tested and the finding probably reflects the capacity of the ruminant to store sperm.

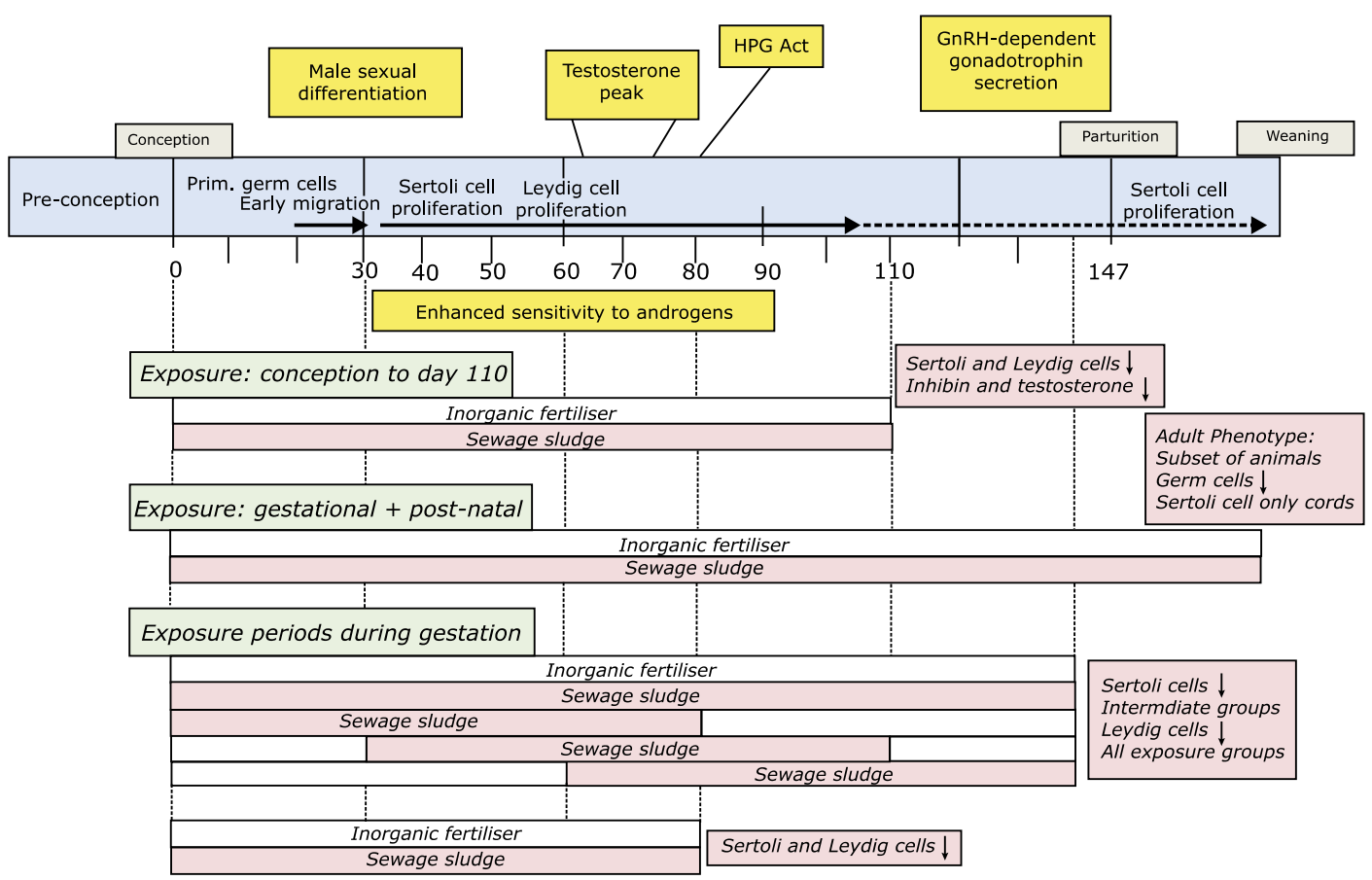

Fig. 1. The effects of EDCs contained in sewage sludge on the developing ovine fetal and post-natal testis. A developmental timeline is presented along with the experimental design and key observations. Pregnant ewes were exposed to sewage sludge fertilised pastures or to control pastures with inorganic fertiliser. Results are presented relating to (a) exposure of the ewes from conception to day 110 followed by euthanasia, (b) exposure throughout pregnancy followed by offspring exposure to weaning and (c) exposed for 80 day periods during early, mid or late pregnancy after which all ewes were euthanized at day 140 . A separate subgroup was euthanized at day 80 . 
These findings raise the following questions: (a) which period(s) of gestation are more sensitive to exposure to EDCs and (b) do EDCs have different mechanistic effects at different stages of gestation. The key stages of fetal testis development are summarised in Fig. 1. To investigate this, we set up an experiment to investigate the impact of exposure of pregnant ewes to sewage sludge during 80-day windows in early, mid or late gestation periods $(0-80$, 30-110 and 60-140 days) and additional groups comprised ewes exposed continuously (0-140 days) and control non-exposed animals (0-140 days). Our preliminary findings indicate that numbers of Sertoli cells at day 140 of gestation were reduced in the 0-80, 30-110 and 60-140 exposed groups but not in animals continuously exposed from 0-140 days (Lea et al. 2010, R G Lea, B Loup, L Purdie, B Mandon-Pepin, M R Amezaga, S M Rhind, C Cotinot, P A Fowler \& K D Sinclair 2014, unpublished observations). In contrast, a sub-group of animals exposed to sewage sludge for 80 days and immediately euthanised, did show reduced numbers of Sertoli cells relative to controls. It is possible therefore that between day 80 and day 140, the Sertoli cells underwent increased proliferation so that no difference was observed at the later time point. Leydig cell numbers showed a different pattern to Sertoli cells and were reduced in animals exposed throughout gestation and in the intermediate groups (Lea et al. 2010, R G Lea, B Loup, L Purdie, B Mandon-Pepin, M R Amezaga, S M Rhind, C Cotinot, P A Fowler \& K D Sinclair 2014, unpublished observations).

In the sewage sludge model, two chemicals were present at greater concentrations in fetal compared to maternal livers: two polychlorinated biphenyl (PCB) congeners (PCB101, 118) and di(2-ethylhexyl)phthalate (DEHP) (Rhind et al. 2009). This observation provided the basis for a second ovine model whereby pregnant ewes were exposed from conception to late gestation (day 140) to environmental concentrations of DEHP, PCB $(101,118)$ or a combination of the two. Our preliminary findings indicate that fetuses from ewes exposed specifically to each chemical independently or to a combination of the two, from conception to day 140, exhibit decreased numbers of Sertoli cells (Lea et al. 2011). This contrasts with the Sewage sludge exposure model where no differences in Sertoli cell numbers were observed at the same stage of gestation. Although the reason for this intriguing difference between the two ovine models is uncertain, it clearly reflects the increased complexity of exposure to a cocktail of EDCs in model 1 as compared to the more controlled exposure to two selected chemicals as described in model 2.

\section{Effects on the fetal hypothalamus and pituitary gland}

Exposure to sewage sludge is associated with perturbations of the fetal hypothalamus and pituitary gland. The regulation of reproduction, by both internal and external environmental factors, occurs at the level of the hypothalamus via gonadotrophin releasing hormone $(\mathrm{GnRH})$ which in turn regulates gonadotrophin $(\mathrm{LH}$ and $\mathrm{FSH}$ ) release from the pituitary gland. Sewage sludge exposure is associated with reduced expression of hypothalamic GNRH1 mRNA and pituitary gland GNRHR mRNA (Bellingham et al. 2010), both of which might result in decreased drive within the hypothalamic-pituitary-gonadal axis. The $\mathrm{GnRH}$ neurosecretory system is not directly regulated by steroids and therefore not at direct risk of steroidogenic EDC effects. However, the above studies also documented reduced mRNA expression of the neuropeptide kisspeptin (KISS1) (Bellingham et al. 2009); a steroid-sensitive GnRH afferent and key regulator of the changes in $\mathrm{GnRH}$ neuronal activity required for pubertal transition and the generation of the preovulatory LH surge (d'Anglemont de Tassigny et al. 2007, Roa et al. 2011). The kisspeptin system is an important potential target for endocrine disruption, which could result in altered reproductive function (Tena-Sempere 2010, Losa et al. 2011). The effects of sewage sludge at the level of the hypothalamus is further supported by downstream effects in the pituitary 
gland, manifest by decreased numbers of LHB immunopositive cells, a reduced number of cells co-expressing LHB and kisspeptin and reduced LHB/oestrogen receptor alpha (ESR1) co-expression in sewage sludge exposed fetuses relative to control animals (Bellingham et al. 2009). These changes could have negative effects on normal regulation of reproductive function. Further effects at the level of the hypothalamic-pituitary gland were seen relative to galanin, a neurotransmitter system involved in the relay of information about the internal environment to the $\mathrm{GnRH}$ neurosecretory system. Maternal sewage sludge exposure was associated with reduced fetal mRNA expression of galanin receptor isoforms in both the hypothalamus and pituitary gland (Bellingham et al. 2010). These studies demonstrate that continuous maternal grazing on sludge treated pastures before and during pregnancy is associated with significant alterations of fetal hypothalamic and pituitary regulators of $\mathrm{GnRH}$ function. Due to the sensitivity of the fetus to exogenous factors and developmental plasticity, such effects could have long term consequences for the reproductive neuroendocrine axis.

\section{Effects on the female}

A number of reports claim a link between exposure to endocrine disruptors and breast cancer, precocious puberty, premature menopause, polycystic ovary syndrome (PCOS), infertility and endometriosis in women (Crain et al. 2008, Bourguignon et al. 2013, Braun et al. 2013, Caserta et al. 2013). Rodent studies have shown that perinatal exposure to environmental chemicals induces precocious puberty, hastens reproductive senescence and induces other abnormalities of female reproductive development (Dickerson \& Gore 2007, Gore et al. 2011). However, the data are contradictory and the evidence for a consistent negative effect of EDCs at subtoxicological doses on fertility in women is controversial (Mascarenhas et al. 2012, Rostad et al. 2013). Part of the problem in humans is the variability and effects of a large number of confounding factors, including occupational vs environmental exposures, many of which cannot be accurately determined. In addition, in human fertility studies the contribution of the partner has to be included in a way that does not directly translate to animal studies (Buck Louis 2013). In ruminants, some EDCs have been reported in bovine follicular fluid however in other papers, EDCs were below the limit of detection (Kamarianos et al. 2003a, Petro et al. 2012).

In female mammals, including the human, the two key events of ovarian differentiation i.e. oogonia meiosis and follicle formation starts during in utero development and only concludes when the oocyte is fertilized (Sarraj \& Drummond 2012) (Fig. 2, 3). Meiotic cell division is unique to germ cells, allowing them to produce haploid cells for sexual reproduction. During fetal life, the first meiotic prophase occurs, and then oocytes may remain arrested at dictyonema for many years in long-lived species (Spiller et al. 2012). In contrast to rodents, early folliculogenesis occurs in utero in ruminants and humans (Fig. 3) (Sathananthan et al. 2000, Sawyer et al. 2002, Baillet et al. 2008), beginning with recruitment of pre-granulosa cells to the oocyte to form the primordial follicle (Pepling 2012). The pool of primordial follicles constitute the ovarian reserve throughout the reproductive period in females (Forabosco \& Sforza 2007) and some are stimulated to grow and develop into primary, secondary or antral follicles. Environmental compounds could, potentially, perturb the function of each of the cell types involved (oocytes and follicular cells). Moreover, EDC exposure during the fetal period can reduce the female's lifetime reserve of oocytes, which cannot be renewed, unlike males in which continuous spermatogenesis may quench transient EDC effects.

In the sewage sludge model, exposure of the female fetus in utero from conception to day 110 of gestation disrupts fetal ovarian development (Fowler et al. 2008). In a follow-up study, the timing of exposure was investigated: ewes were exposed pre-mating, post-conception 


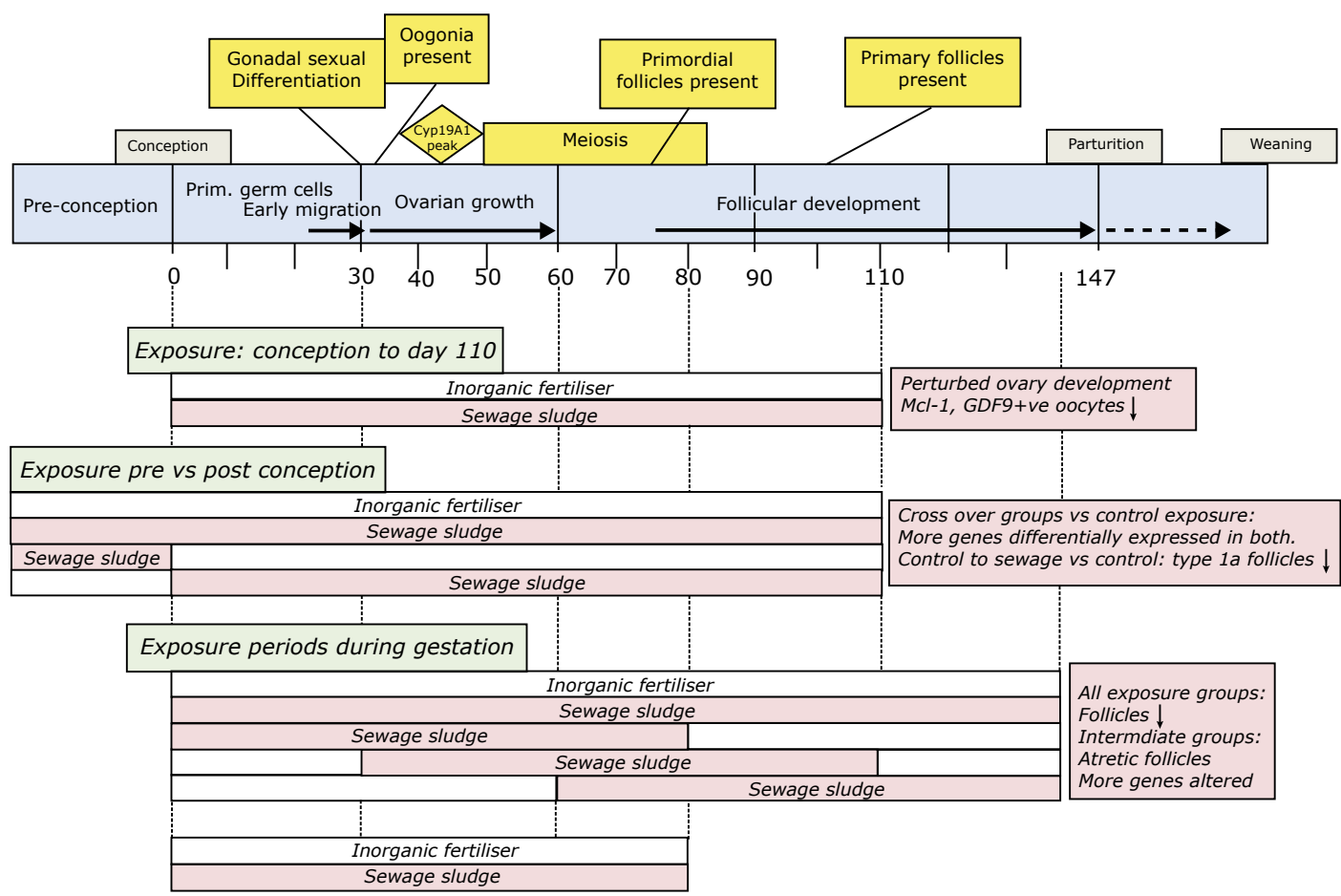

Fig. 2. The effects of EDCs contained in sewage sludge on the developing ovine fetal and post-natal ovary. A developmental timeline is presented along with the experimental design and key observations. Pregnant ewes were exposed to sewage sludge fertilised pastures or to control pastures with inorganic fertiliser. Results are presented relating to (a) exposure of the ewes from conception to day 110 followed by euthanasia, (b) exposure prior to conception or post-conception, with a cross over to control or sewage sludge exposure through to day 110, (c) exposed for 80 day periods during early, mid or late pregnancy after which all ewes were euthanized at day 140. A separate subgroup was euthanized at day 80 .

or throughout both periods (Fig. 2). Ewes switched from control to sewage sludge at mating exhibited fewer follicles than those exposed throughout both periods (Bellingham et al. 2013). In addition, both cross exposure groups exhibited a greater number of gene expression changes compared to ewes continuously exposed to sewage sludge or control pastures. Thyroid glands from these animals were also most affected in these groups (Hombach-Klonisch et al. 2013). Consequently, a change in fetal ovarian environment, even to a reduced exposure to EDCs, appears to be more detrimental than a consistent period of exposure to normal or elevated levels of EDCs. Chronic exposure probably induces an increased detoxification in both mother and fetus highlighting the resilience capacity of the reproductive system.

Further recent studies have investigated which periods of gestation are the more sensitive to chemical exposure, using the experimental design as described above for males. Our preliminary findings indicate that follicle numbers are reduced in all exposure groups, with higher proportions of atretic follicles in the mid and late gestation groups. Moreover, transcriptomics revealed greater numbers of differentially expressed genes in the mid and late gestation windows. Thus similar to the pre- to post-conception switch over study, a change in environment appears to be more detrimental than continuous exposure. However, the preliminary data also suggest that primordial follicle formation, arrest and development may be particularly susceptible to exposure to EDCs 


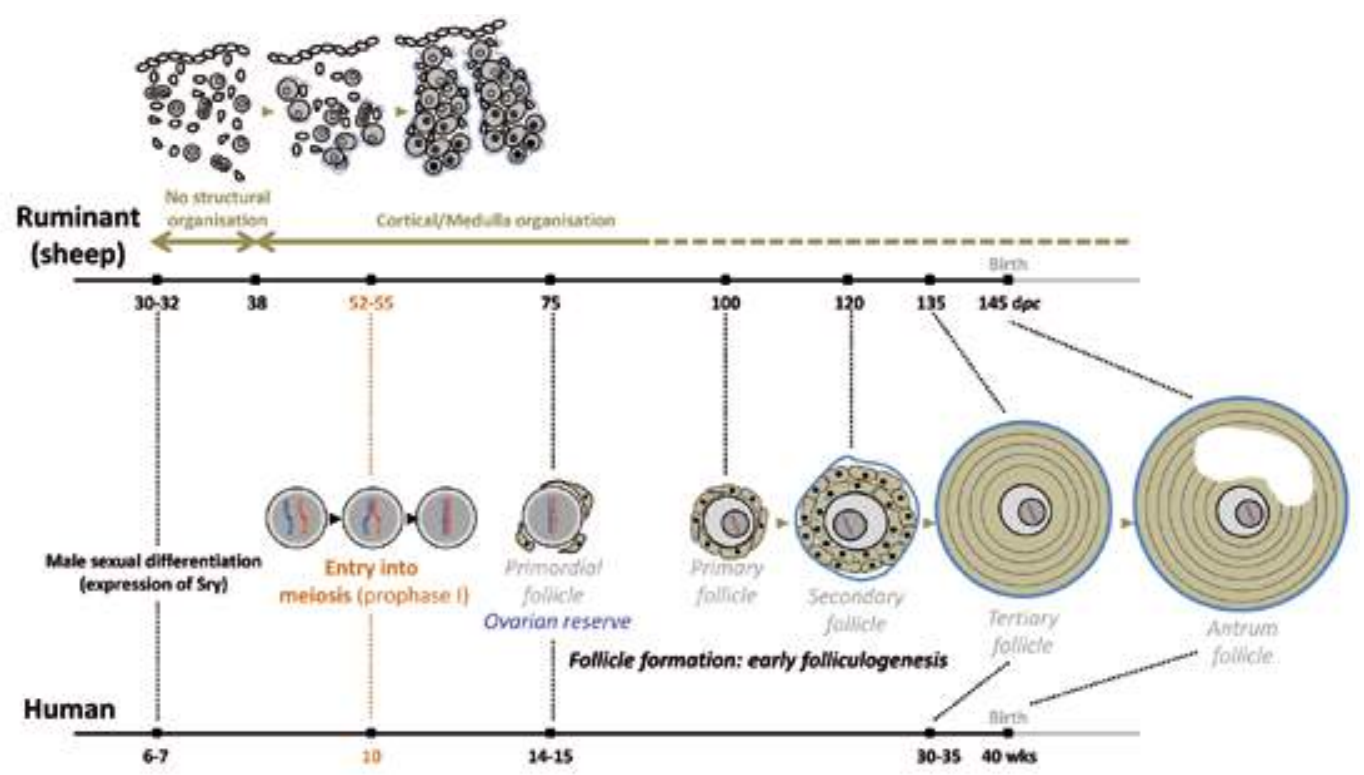

Fig. 3. Timeline of the major cellular events in mammalian ovary morphogenesis. During embryogenesis, the bipotential gonad is formed at the end of the first month of pregnancy in humans and sheep. The switch between male and female occurs a few days later. In the XX gonad, where $S R Y$ is absent, events in testis morphogenesis do not happen. Specification of the granulosa cell lineage defines the first step of ovary organogenesis (35-38dpc in sheep, 8 weeks in humans). This step is under the control of genes expressed specifically in the female such as FOXL2 and RSPO1. Female germ cells within the germ cell nest begin to enter meiosis at 52-55dpc in sheep (9-10 weeks of gestation in humans) and arrest in the diplotene stage of meiosis I beginning at $75 \mathrm{dpc}$ (14-15 weeks in humans). The germ cell nests break down soon after to form primordial follicles. Follicle activation compartmentalizes the somatic cell environment, accompanied by the recruitment of theca cells to the primary follicle (100-110dpc in sheep, 20 weeks in humans).

contained within sewage sludge (Loup et al. 2011, R G Lea, M R Amezaga, B Loup, B MandonPépin, M Fraser, C Kyle, C Kerr, M Osprey, Z Zhang, C Allen, L Purdie, K D Sinclair, C Cotinot, S M Rhind \& P A Fowler 2014, unpublished observations).

In a separate study, ovine female foetuses, maternally exposed to relatively low concentrations of bisphenol A (BPA), showed altered expression of ovarian steroidogenic enzymes and micro RNAs relevant to gonadal development and function. In support of the sewage sludge model data, gene expression investigated at days 65 and 90 revealed clear gestation day differences (Veiga-Lopez et al. 2013). Although we have not yet characterised a female adult phenotype in the sewage sludge model, pre-pubertal exposure to BPA or the organochlorine pesticide, methoxychlor (MXC), has been shown to alter post-pubertal reproductive function. This was manifest by a reduced LH surge amplitude in response to BPA and a delayed onset of the LH surge in response to MXC (Savabieasfahani et al. 2006). Interestingly, recent mechanistic studies indicate that this likely reflects altered follicular development and steroidogenesis in the ovary (Abi Salloum et al. 2013).

\section{In vitro models parallel in vivo studies}

Biologically relevant bioassays are needed for dose-response tests of EDC effects on steroidogenesis and gametogenesis and to understand the mechanisms of action by which 
EDCs act on their targets to disrupt the normal processes of cellular differentiation. This has been demonstrated in the male where biologically relevant concentrations of the pesticide dieldrin have been shown to reduce testosterone secretion by human fetal testis explants (Fowler et al. 2007). However, because disturbances in the endocrine system can affect multiple systems, understanding the effects of EDCs is best accomplished by combining in vitro with in vivo approaches. Mouse follicle culture models are useful in studying folliculogenesis and oogenesis, (Cortvrindt \& Smitz 2002) and in analysing the endocrine disruption of steroid biosynthesis (Myllymaki et al. 2005, Lenie \& Smitz 2009). One mouse follicle culture model allows the individual and synchronous growth of a large number of follicles from early preantral to preovulatory stages of folliculogenesis (Cortvrindt \& Smitz 2002). BPA exposed oocytes present unbalanced chromosome sets, decreased conceptions and are more prone to pregnancy loss than non-exposed oocytes in vitro (Can et al. 2005, Eichenlaub-Ritter et al. 2008, Lenie \& Smitz 2009). Furthermore, the effects of several PCB mixtures have been tested on in vitro maturation and fertilization of mouse oocytes (Kholkute et al. 1994, Kholkute \& Dukelow 1997). The addition of PCB mixtures at concentrations ranging from 0.01 to $10 \mu \mathrm{g} /$ $\mathrm{ml}$, affected the fertilisability of the oocytes. The exposure of bovine oocytes to a mixture of PCBs showed a dose-dependent increase in the percentage of oocytes unable to complete the maturation process to metaphase II. Moreover, the adverse effects of exposure to PCBs extended to fertilization and further embryonic development even after the removal of PCBs from the culture medium (Pocar et al. 2001). Exposure of bovine cumulus-oocyte-complexes (COC) to coplanar PCBs affected maturation and a significant increase in apoptosis and BAX mRNA expression occurred at doses as low as $100.6 \mathrm{pg} / \mathrm{ml}$ (Pocar et al. 2005).

The development of an in vitro culture system mimicking cellular interactions and supporting the growth and differentiation of fetal ovaries is a crucial step for testing and understanding EDC effects. Indeed, in vitro culture systems allow kinetic and dose-dependent studies of toxicological agents in human fetal organs. Organ culture is an approach requiring a small quantity of biological material and may be an alternative to animal experiments. Several groups have developed human fetal ovarian in vitro cultures to test the effects of EDC exposures (Angenard et al. 2011, Brieno-Enriquez et al. 2011, 2012, Poulain et al. 2012). Human fetal BPA-exposed oocytes showed a delay in meiotic progression and oocytes exposed to BPA show an up-regulation of genes involved in double strand break generation, signalling and repair (Brieno-Enriquez et al. 2011, 2012).

The development and validation of a ruminant in vitro organ culture system allows individual chemical (BPA, DEHP and PCB) and mixture effects on early ovarian development to be tested (C Cotinot, personal communication). For this purpose, we optimised the culture conditions for two fetal sheep developmental stages (50-70 days and 90-120 days post coitum (dpc) (Fig. 4). Day 50-70pc corresponds to prophase I of meiotic division of oocytes (11-22 weeks of development of human fetal ovaries, Fig. 3) while 90-120dpc corresponds to ovarian follicle formation (early folliculogenesis, 18-28 weeks in human, Fig. 3). Ovarian folliculogenesis is complex and is regulated by various endocrine, paracrine, and autocrine factors. For these reasons, we developed a long-term organ culture system in which three ovarian fragments per fetal ovary were placed on an insert floating at the surface of culture medium and maintained for 20 days (Fig. 4). This enabled the study of the onset and completion of prophase I meiosis (50-70 dpc), the transition of primordial to primary follicles $(90-110 \mathrm{dpc})$ and the transition of primary to secondary or antral follicles $(110-130 \mathrm{dpc})$. Mixtures of chemicals, at all environmental concentrations tested $\left(10^{-6} \mathrm{M}\right.$ and $\left.10^{-8} \mathrm{M}\right)$, induced more changes in ovarian transcriptomes than chemical molecules tested alone (Mandon-Pépin et al. 2013). However, there were no significant differences in morphology or follicle numbers between exposed and non-exposed cultures. 


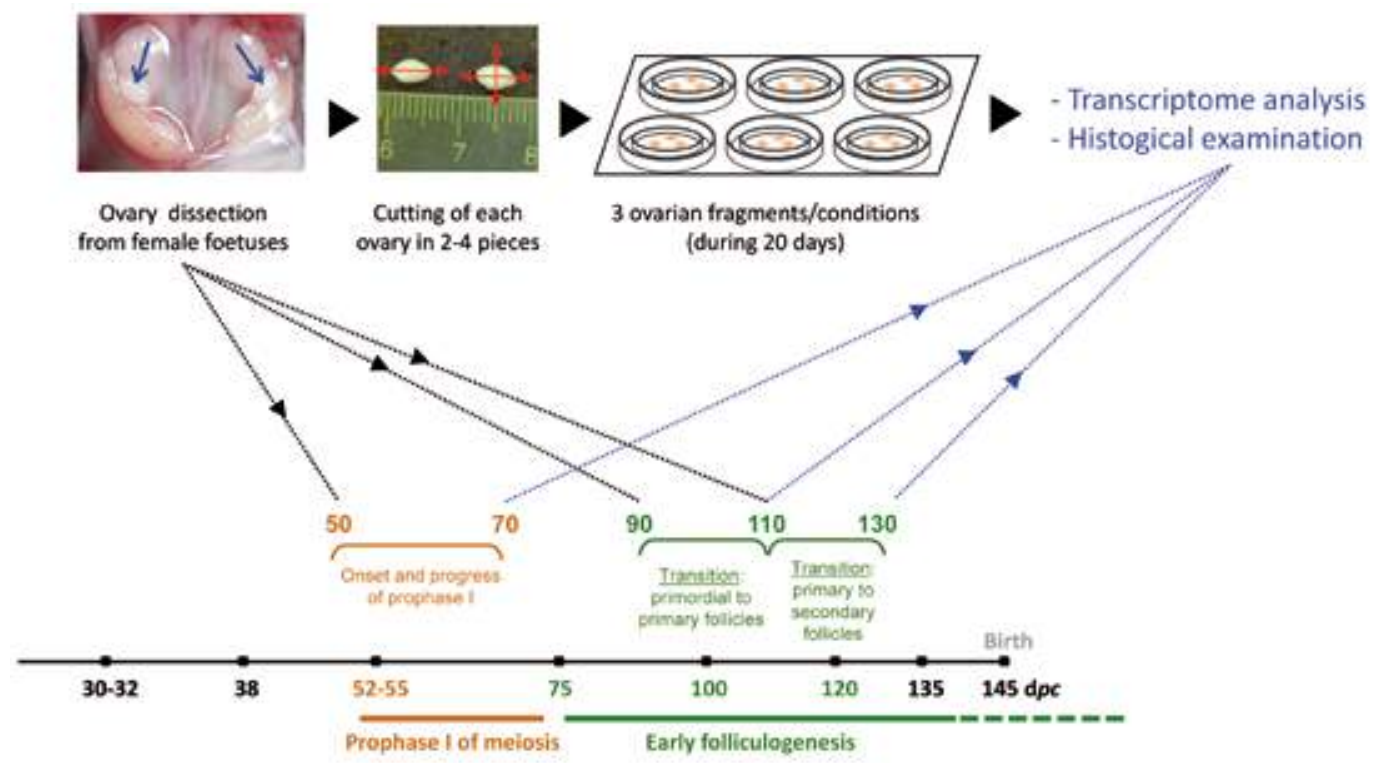

Fig. 4. Ruminant in vitro ovary culture system. The ovaries were removed aseptically from the fetuses at different developmental stages. Ovary explants were cut into pieces of a similar size, specifically two $(50 \mathrm{dpc})$, or four $(90-130 \mathrm{dpc})$ according to the stage. Three ovarian fragments were used for each condition. The filters bearing the explants were floated on $0.5 \mathrm{ml}$ (early stages) or $1.2 \mathrm{ml}$ (later stages) culture medium in tissue culture dishes and incubated at $37^{\circ} \mathrm{C}$, in a humidified atmosphere containing $95 \%$ air $/ 5 \% \mathrm{CO}_{2}$. The ovaries were cultured for 20 days with the medium being replaced once per day. Cultured ovaries were fixed in Bouin's fluid, embedded in paraffin and cut into 7- $\mu$ m-thick sections for histological examination. Ovaries were also frozen at $-80^{\circ} \mathrm{C}$ for molecular analyses.

The impact of BPA, DEHP and PCB on the fetal ovarian transcriptome is greater following in vivo exposure than following in vitro exposure. These differences may reflect i) chemical biotransformation in intact animals that does not occur in organ culture (metabolites were not tested in vitro); ii) other chemicals present in vivo acting in synergy with tested chemicals or their metabolites; iii) indirect effects in vivo through adverse effects on the hypothalamicpituitary axis or other organs. These findings suggest that in vitro studies must be used for the understanding of the action mechanisms of one molecule rather than the characterization of gonad phenotype after exposure to a complex mixture.

\section{Sentinels of EDC exposure: from ruminants to companion animals}

In recent years, increased public awareness of toxic environmental chemicals has led to changes in manufacturing practices for food packaging, baby bottles and other products. It follows therefore that heightened awareness of EDCs in agriculture will focus further attention on domestic animal production systems and the potential consequences of dietary exposure to the consumer. A Swedish study examining levels of EDCs in food products identified fish as the primary source of dietary EDCs with dairy and meat coming second and third respectively (Tornkvist et al. 2011). While dairy products contain higher concentrations of polybrominated diphenyl ethers (PBDEs), they contribute less than meat overall due to consumption levels (Voorspoels et al. 2007). In Belgium, a range of EDCs have been detected in bovine tissues and in Scotland, a similar range has been detected in ovine meat albeit at variable levels depending 
on the regional source (Petro et al. 2010, Rhind et al. 2011). Therefore the presence of EDCs in ruminant derived food products and contamination of agricultural land with toxic substances contained in processed human sewage sludge fertiliser, pesticides and herbicides emphasizes the importance and relevance of a ruminant sentinel model.

From the first reference in the academic literature a century ago of the canary being used to detect dangerous levels of carbon monoxide (Burrell \& Seibert 1914), through the 'dancing' cats of the Minamata Bay region of Japan showing symptoms of methyl mercury poisoning (Rabinowitz et al. 2009), to bees and their honey being used as a biomonitor of pesticide use (Panseri et al. 2014) and brominated flame retardants in the environment (Mohr et al. 2014), the idea of a sentinel model is not new. In identifying an appropriate sentinel or biomonitor (term often used interchangeably with sentinel) for a target species, interspecies variability due to longevity, trophic level and diet, metabolism and habitat must be considered. Examples of sentinels are summarised in Table 1.

Table 1. Literature matrix showing strength of sentinel models with the human as the target species. ${ }^{1}$

\begin{tabular}{|c|c|c|c|c|}
\hline $\begin{array}{l}\text { Sentinel } \\
\text { Model }\end{array}$ & Research Focus & $\begin{array}{l}\text { Animal } \\
\text { Category }\end{array}$ & Criteria Match & Reference \\
\hline Feline & $\begin{array}{l}\text { Low level chronic exposure } \\
\text { to PBDE }\end{array}$ & Companion & Trophic level, Habitat & (Dye et al. 2007) \\
\hline Canine & Metal concentration in tissue. & Companion & $\begin{array}{l}\text { Trophic level, Diet, Metabolism, } \\
\text { Habitat }\end{array}$ & $\begin{array}{l}\text { (Lopez-Alonso et al. } \\
\text { 2007) }\end{array}$ \\
\hline Canine & PCBs & Companion & $\begin{array}{l}\text { Trophic level, Diet, Metabolism, } \\
\text { Habitat }\end{array}$ & (Schilling et al. 1988) \\
\hline $\begin{array}{l}\text { Canine/ } \\
\text { Feline }\end{array}$ & TCDD & Companion & $\begin{array}{l}\text { Trophic level, Diet, }{ }^{2} \text { Metabolism, } \\
\text { Habitat }^{2}\end{array}$ & $\begin{array}{l}\text { (Schilling \& Stehr- } \\
\text { Green 1987) }\end{array}$ \\
\hline Canine & Lead & Companion & $\begin{array}{l}\text { Trophic level, Diet, Metabolism, } \\
\text { Habitat }\end{array}$ & (Enriquez et al. 2009) \\
\hline Ovine & $\begin{array}{l}\text { Tissue levels of many EDCs, } \\
\text { reproductive development and } \\
\text { adult phenotype }\end{array}$ & Ruminant & $\begin{array}{l}\text { Habitat: exposure to EDCs in } \\
\text { sewage sludge fertilizer }\end{array}$ & (Rhind et al. 2009) \\
\hline Bovine & Sperm quality & Ruminant & Habitat: as Ovine & (Wahl \& Reif 2009) \\
\hline Bovine & $\begin{array}{l}\text { Tissue and fluid levels of PCBs, } \\
\text { OCPs, PBDEs }\end{array}$ & Ruminant & Habitat: as Ovine & (Petro et al. 2010) \\
\hline Primate & $\begin{array}{l}\text { Germ cell differentiation/ } \\
\text { testicular germ cell tumour }\end{array}$ & Wildlife & $\begin{array}{l}\text { Longevity, Trophic level, Diet, } \\
\text { Metabolism }\end{array}$ & (Mitchell et al. 2008) \\
\hline Mink & Mercury, PCB & Wildlife & Trophic level, Diet & (Basu et al. 2007) \\
\hline Polar Bear & $\mathrm{OHCs}$ & Wildlife & $\begin{array}{l}\text { Longevity, Trophic level, Diet, } \\
\text { Metabolism }\end{array}$ & (Sonne et al. 2006) \\
\hline $\begin{array}{l}\text { Marine } \\
\text { Mammals }\end{array}$ & Anthropogenic toxins & Wildlife & Longevity, Species dependent & (Bossart 2011) \\
\hline $\begin{array}{l}\text { Domestic } \\
\text { Animals }\end{array}$ & EDCs & General & Species dependent & (Majdič 2010) \\
\hline $\begin{array}{l}\text { Companion } \\
\text { Animals }\end{array}$ & $\begin{array}{l}\text { Public health/environmental } \\
\text { contaminants }\end{array}$ & Companion & Species dependent & (Schmidt 2009) \\
\hline Mammals & $\begin{array}{l}\text { Toxic environmental } \\
\text { contaminants }\end{array}$ & General & Species dependent & (O’Brien et al. 1993) \\
\hline Animals & Environmental Chemicals & General & Species dependent & $\begin{array}{l}\text { (van der Schalie et al. } \\
\text { 1999) }\end{array}$ \\
\hline
\end{tabular}

${ }^{1}$ Criteria considered in model validity are longevity, trophic level, diet, metabolism and habitat. ${ }^{2}$ Canine only. EDC: endocrine disrupting chemical, PBDE: polybrominated diphenyl ether, PCB: polychlorinated biphenyl, TCDD: tetrachlorobenzodioxin, OCP: organochlorine pesticides, OHC: organohalogen pollutants 
Companion animals have been used as sentinel models for human exposure to EDCs. Established in Japan, the feline model is a useful sentinel for methyl mercury (Takeuchi et al. 1977) and PBDE in humans (Dye et al. 2007, Guo et al. 2012). Similarly, the dog has been proposed as a sentinel of human exposure to EDCs and we have recently identified a decline in canine semen quality which parallels that in humans (Byers et al. 2012) while an increased incidence of testicular tumours in dogs is evidence for canine TDS (Grieco et al. 2008). We have also identified specific EDCs in adult dog testes and the same chemicals in a range of commercially available dog foods is indicative of a nutritional link (Byers et al. 2012). Since the dog occupies the same environment as the human and is a carnivore, it may be an excellent sentinel of human exposure to EDCs particularly, but not exclusively, via the diet. Since a majority of the meat consumed by humans and companion animals is derived from ruminants, studies of the dog as a sentinel for human EDC exposure provides key information on the potential impact of ruminant meat-derived EDCs on the consumer. Interestingly, the accumulation of EDCs in Greenland people through the consumption of a high fat marine mammal based diet has been modelled by feeding Minke whale blubber fed to sled dogs (Verreault et al. 2008, Bonefeld-Jorgensen 2010). EDCs were not only traced through to adipose tissue in these animals but also to the offspring at pre- and post-weaning stages (Kirkegaard et al. 2011).

The use of sentinel models, especially for chronic exposure to ambient levels of environmental EDCs, provides insight not gained from experimental models. The canine sentinel model, based on the consideration of longevity, trophic level and diet, metabolism and habitat, is most useful in understanding EDCs and human health. The dog may be a useful biomonitor of dietary exposure for other target species such as polar bears (Verreault et al. 2008), which proves the versatility of these sentinel models. In the case of the ruminant, the bull has already contributed as a sentinel model to the weight of the argument suggesting a temporal decrease in semen quality.

\section{Rodent models of EDC exposure: transgenerational and epigenetic effects}

Many published studies on the effects of EDCs use rodent models, and often focus on single chemicals applied at relatively high concentrations in vivo. However, this by no means applies to all rodent studies. Indeed, a rat model of in utero exposure to di(n-butyl) phthalate at human relevant levels exhibits many of the features characterising human TDS (Fisher et al. 2003). Moreover a window of sensitivity (masculinization programming window) has been identified during which environmental chemicals are effective in perturbing testis development and inducing TDS like symptoms in male offspring (Welsh et al. 2008). This therefore provides a model whereby mechanisms can be established and tested in other sentinel and experimental model species. A key advantage of the rodent model is the investigation of mutigenerational or transgenerational effects of EDC exposure in utero and/or during lactation. Pocar et al. recently reported that the exposure of mice during pregnancy and lactation to a mix of PCB congeners (101 and 118) at concentrations comparable to human exposures impaired testis development, sperm counts, ovarian development and oocyte quality in F1 offspring (Pocar et al. 2012). Furthermore, reduced sperm viability and altered seminiferous tubule development up to the $\mathrm{F}_{3}$ generation were observed.

There is compelling evidence from rodent studies that some of the effects of environmental chemicals, such as diethylstilbestrol (DES) (Alworth et al. 2002) and the isoflavonoid 
phytoestrogen genistein (Tang et al. 2008), are mediated via epigenetic changes to DNA methylation. Anway and colleagues (Anway et al. 2005) went further to demonstrate malegermline mediated epigenetic transgenerational effects of the anti-androgenic compound vinclozolin (an agricultural fungicide) and the oestrogenic compound methoxchlor on gonadal sex determination, which persisted to the $F_{3}$ generation in the rat. However, because the $F_{0}$ gestating female is exposed to environmental stimuli, both the $F_{1}$ embryo and $F_{2}$ generation germ line are also directly exposed (Jirtle \& Skinner 2007). Consequently, for epigenetic modifications to chromatin to be considered a plausible mechanism for transgenerational inheritance of phenotypic change, effects need to persist to at least the $F_{3}$ generation. However to date there is no direct link between exposure to environmental chemicals and epigenetic dysregulation of gene expression that relate to aberrant gonadal development and adverse fertility phenotypes in farm animal species. This is primarily because these mechanisms have not been investigated in this context in these species.

\section{Conclusions}

The evolutionary void between human and ruminant is even wider than between human and rodent. However, in many ways the patterns of reproductive and developmental events are much more similar between ruminant and human while key developmental events, such as primordial follicle formation, do not occur in utero but, instead, occur post-natally in the rodent. While in mechanistic terms there is much in common between ruminants, humans and rodents in terms of the processes, the events occurring post-natally in the rodent will, inevitably, be exposed to different chemicals (e.g. via lactation) and environmental influences than the human or ruminant e.g. direct exposure to the environment instead of in utero via the mother. In terms of digestion and metabolism there are, of course, some marked differences and similarities between ruminants, humans and rodents, such as hepatic recirculation (Mazur et al. 2010), which can be associated with considerable differences in internal chemical exposures despite a similar external dose. Notwithstanding the role of the rumen in exacerbating human-ruminant differences in digestion, internal dosage is still likely to be more similar between humans and ruminants. In one respect almost all species conduct their pregnancies at relatively low oestrogen levels compared with humans (human gestational steroid reviewed in Kuijper et al. 2013). In addition, the activity of the human fetal liver as a detoxification and steroidogenic organ (O'Shaughnessy et al. 2013) is markedly different from the rodent. The take-home message is that endocrine disruption is best studied in a number of laboratory and sentinel species in order to properly account for inter-species differences in exposure, internal dosage, metabolism and phenotypic response (Fig. 5). The sheep, especially housed outdoors with biosolids exposure is therefore an excellent model to better understand the reproductive consequences of endocrine disruption. 


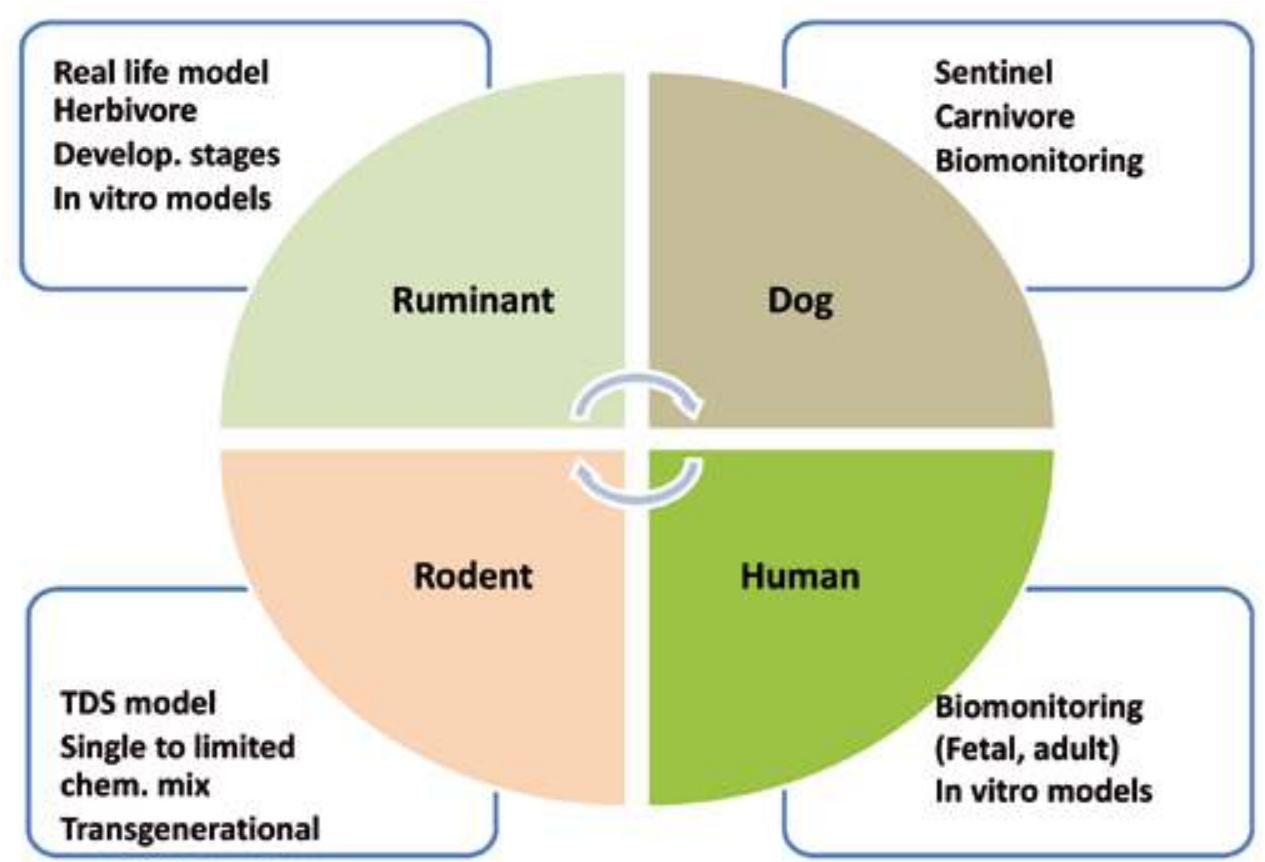

Fig. 5. Roles of experimental animal models and sentinel species in determining the reproductive impact of endocrine disrupting chemicals. Ruminant: Sheep exposed to a cocktail of chemicals contained in sewage sludge constitute a real life ruminant (herbivore) model of human exposure. The long period of gestation and well characterised stages of fetal development facilitate the elucidation of EDC effects at specific developmental stages. An established in vitro ovary culture system enables individual chemical and mixture effects to be determined. Rodent: An established rodent model of testicular dysgenesis syndrome (TDS) provides information on mechanism. The short gestation period has been exploited to investigate transgenerational effects. Dog: The dog is a recognised (carnivore) sentinel for human exposure to EDCs and gonad chemical analysis provides a means of biomonitoring. Human: Analysis of chemical profiles in adult and fetal samples/tissues provides a means of direct biomonitoring and gonad explant culture systems enable the direct effects of EDCs on human fetal tissues to be determined.

\section{Acknowledgements}

In memory of Stewart Rhind and his contribution to the field.

\section{References}

Abi Salloum B, Steckler TL, Herkimer C, Lee JS \& Padmanabhan V 2013 Developmental programming: impact of prenatal exposure to bisphenol-A and methoxychlor on steroid feedbacks in sheep. Toxicology and Applied Pharmacology 268 300-308.

Alworth LC, Howdeshell KL, Ruhlen RL, Day JK, Lubahn DB, Huang TH, Besch-Williford CL \& vom Saal FS 2002 Uterine responsiveness to estradiol and DNA methylation are altered by fetal exposure to diethylstilbestrol and methoxychlor in CD-1 mice: effects of low versus high doses. Toxicology and Applied Pharmacology 183 10-22.
Angenard G, Muczynski V, Coffigny H, Duquenne C, Frydman R, Habert R, Livera G \& Rouiller-Fabre V 2011 In vitro effects of Uranium on human fetal germ cells. Reproductive Toxicology 31 470-476.

Anway MD, Cupp AS, Uzumcu M \& Skinner MK 2005 Epigenetic transgenerational actions of endocrine disruptors and male fertility. Science 308 1466-1469.

Baillet A, Mandon-Pepin B, Cabau C, Poumerol E, Pailhoux E \& Cotinot C 2008 Identification of transcripts involved in meiosis and follicle formation during ovine ovary development. BMC Genomics 9436.

Basu N, Scheuhammer AM, Bursian SJ, Elliott J, Rouvinen- 
Watt K \& Chan HM 2007 Mink as a sentinel species in environmental health. Environmental Research 103 130-144.

Bellingham M, Fowler PA, Amezaga MR, Rhind SM, Cotinot C, Mandon-Pepin B, Sharpe RM \& Evans NP 2009 Exposure to a complex cocktail of environmental endocrine-disrupting compounds disturbs the kisspeptin/GPR54 system in ovine hypothalamus and pituitary gland. Environmental Health Perspectives 117 1556-1562.

Bellingham M, Fowler PA, Amezaga MR, Whitelaw CM, Rhind SM, Cotinot C, Mandon-Pepin B, Sharpe RM \& Evans NP 2010 Foetal hypothalamic and pituitary expression of gonadotrophin-releasing hormone and galanin systems is disturbed by exposure to sewage sludge chemicals via maternal ingestion. Journal of Neuroendocrinology 22 527-533.

Bellingham M, McKinnell C, Fowler PA, Amezaga MR, Zhang Z, Rhind SM, Cotinot C, Mandon-Pepin B, Evans NP \& Sharpe RM 2012 Foetal and post-natal exposure of sheep to sewage sludge chemicals disrupts sperm production in adulthood in a subset of animals. International Journal of Andrology 35 317-329.

Bellingham M, Amezaga MR, Mandon-Pepin B, Speers CJ, Kyle CE, Evans NP, Sharpe RM, Cotinot C, Rhind SM \& Fowler PA 2013 Exposure to chemical cocktails before or after conception - the effect of timing on ovarian development. Molecular and Cellular Endocrinology 376 156-172.

Bergstrom R, Adami HO, Mohner M, Zatonski W, Storm H, Ekbom A, Tretli S, Teppo L, Akre O \& Hakulinen T 1996 Increase in testicular cancer incidence in six European countries: a birth cohort phenomenon. Journal of the National Cancer Institute 88 727-733.

Bonefeld-Jorgensen EC 2010 Biomonitoring in Greenland: human biomarkers of exposure and effects - a short review. Rural Remote Health 101362.

Bossart GD 2011 Marine mammals as sentinel species for oceans and human health. Veterinary Pathology 48 676-690.

Bourguignon JP, Franssen D, Gerard A, Janssen S, Pinson A, Naveau E \& Parent AS 2013 Early neuroendocrine disruption in hypothalamus and hippocampus: developmental effects including female sexual maturation and implications for endocrine disrupting chemical screening. Journal of Neuroendocrinology 25 1079-1087.

Braun JM, Just AC, Williams PL, Smith KW, Calafat AM \& Hauser R 2013. Personal care product use and urinary phthalate metabolite and paraben concentrations during pregnancy among women from a fertility clinic. Journal of Exposure Science and Environmental Epidemiology, doi: 10.1038/jes.2013.69.

Brieno-Enriquez MA, Robles P, Camats-Tarruella N, Garcia-Cruz R, Roig I, Cabero L, Martinez F \& Caldes MG 2011 Human meiotic progression and recombination are affected by Bisphenol A exposure during in vitro human oocyte development. Human Reproduction 26 2807-2818.

Brieno-Enriquez MA, Reig-Viader R, Cabero L, Toran N, Martinez F, Roig I \& Garcia Caldes M 2012 Gene expression is altered after bisphenol A exposure in human fetal oocytes in vitro. Molecular Human Reproduction 18 171-183.

Buck Louis GM 2013 Persistent Enviornmental Pollutants and couple Fecundity. Reproduction 147 R97-R104.

Burrell G \& Seibert F 1914 Experiments with small animals and carbon monoxide. Journal of Industrial and Engineering Chemistry 6 241-244.

Butkiewicz D, Grzybowska E, Phillips DH, Hemminki K \& Chorazy M 2000 Polymorphisms of the GSTP1 and GSTM1 genes and PAH-DNA adducts in human mononuclear white blood cells. Environmental and Molecular Mutagenesis 35 99-105.

Byers AS, Rhind SM, Zhang ZL, Green M, Moxon R, Freeman S, England GCW \& Lea RG 2012 Endocrine disrupting chemicals in dog testis and a range of dog foods: is the dog a sentinel for human exposure? Society for Reproduction and Fertility, 61st Annual Congress, pp. 40, Abstract P039.

Can A, Semiz O \& Cinar O 2005 Bisphenol-A induces cell cycle delay and alters centrosome and spindle microtubular organization in oocytes during meiosis. Molecular Human Reproduction 11 389-396.

Carlsen E, Giwercman A, Keiding N \& Skakkebaek NE 1992 Evidence for decreasing quality of semen during past 50 years. British Medical Journal 305 609-613.

Carson R 1962 Silent Spring. Boston, New York: Houghton Mifflin Company.

Caserta D, Bordi G, Ciardo F, Marci R, La Rocca C, Tait S, Bergamasco B, Stecca L, Mantovani A, Guerranti C, Fanello EL, Perra G, Borghini F, Focardi SE \& Moscarini M 2013 The influence of endocrine disruptors in a selected population of infertile women. Gynecological Endocrinology 29 444-447.

Cortvrindt RG \& Smitz JE 2002 Follicle culture in reproductive toxicology: a tool for in-vitro testing of ovarian function? Human Reproduction Update 8 243-254.

Crain DA, Janssen SJ, Edwards TM, Heindel J, Ho SM, Hunt P, Iguchi T, Juul A, McLachlan JA, Schwartz J, Skakkebaek N, Soto AM, Swan S, Walker C, Woodruff TK, Woodruff TJ, Giudice LC \& Guillette LJ Jr 2008 Female reproductive disorders: the roles of endocrinedisrupting compounds and developmental timing. Fertility and Sterility 90 911-940.

d'Anglemont de Tassigny X, Fagg LA, Dixon JP, Day K, Leitch HG, Hendrick AG, Zahn D, Franceschini I, Caraty A, Carlton MB, Aparicio SA \& Colledge WH 2007 Hypogonadotropic hypogonadism in mice lacking a functional Kiss 1 gene. Proceedings of the National Academy of Sciences USA 104 10714-10719.

Dickerson SM \& Gore AC 2007 Estrogenic environmental endocrine-disrupting chemical effects on reproductive neuroendocrine function and dysfunction across the life cycle. Reviews in Endocrine and Metabolic Disorders 8 143-159.

Dye JA, Venier M, Zhu L, Ward CR, Hites RA \& Birnbaum LS 2007 Elevated PBDE levels in pet cats: sentinels for humans? Environmental Science and Technology 41 6350-6356.

Eichenlaub-Ritter U, Vogt E, Cukurcam S, Sun F, 
Pacchierotti F \& Parry J 2008 Exposure of mouse oocytes to bisphenol A causes meiotic arrest but not aneuploidy. Mutation Research 651 82-92.

Enriquez B, Hakou G, Tabaries A, Revol B, Le Moal J, Sasco A \& Bénet J 2009 Les chiens sentinelles du risque en toxicologie environnementale : intérêt dans la prévention du saturnisme humain; première étude menée sur I'ENVA. Épidémiologie et Santé Animale 56 233-241.

Fisher JS, Macpherson S, Marchetti N \& Sharpe RM 2003 Human 'testicular dysgenesis syndrome': a possible model using in-utero exposure of the rat to dibutyl phthalate. Human Reproduction 18 1383-1394.

Forabosco A \& Sforza C 2007 Establishment of ovarian reserve: a quantitative morphometric study of the developing human ovary. Fertility and Sterility $\mathbf{8 8}$ 675-683.

Fowler PA, Abramovich DR, Haites NE, Cash P, Groome NP, Al-Qahtani A, Murray TJ \& Lea RG 2007 Human fetal testis Leydig cell disruption by exposure to the pesticide dieldrin at low concentrations. Human Reproduction 22 2919-2927.

Fowler PA, Dora NJ, McFerran H, Amezaga MR, Miller DW, Lea RG, Cash P, McNeilly AS, Evans NP, Cotinot C, Sharpe RM \& Rhind SM 2008 In utero exposure to low doses of environmental pollutants disrupts fetal ovarian development in sheep. Molecular Human Reproduction 14 269-280.

Gore AC, Walker DM, Zama AM, Armenti AE \& Uzumcu M 2011 Early life exposure to endocrine-disrupting chemicals causes lifelong molecular reprogramming of the hypothalamus and premature reproductive aging. Molecular Endocrinology 25 2157-2168.

Grieco V, Riccardi E, Veronesi MC, Giudice C \& Finazzi M 2008 Evidence of testicular dysgenesis syndrome in the dog. Theriogenology 70 53-60.

Guo W, Park JS, Wang Y, Gardner S, Baek C, Petreas M \& Hooper K 2012 High polybrominated diphenyl ether levels in California house cats: house dust a primary source? Environmental Toxicology and Chemistry 31 301-306.

Hombach-Klonisch S, Danescu A, Begum F, Amezaga MR, Rhind SM, Sharpe RM, Evans NP, Bellingham M, Cotinot C, Mandon-Pepin B, Fowler PA \& Klonisch T 2013 Peri-conceptional changes in maternal exposure to sewage sludge chemicals disturbs fetal thyroid gland development in sheep. Molecular and Cellular Endocrinology 367 98-108.

Jackson MB, Chilvers C, Pike MC, Ansell P \& Bull D 1986 Cryptorchidism: an apparent substantial increase since 1960. John Radcliffe Hospital Cryptorchidism Study Group. British Medical Journal (Clinical Research Ed.) 293 1401-1404.

Jirtle RL \& Skinner MK 2007 Environmental epigenomics and disease susceptibility. Nature Reviews Genetics 8 253-262.

Jorgensen $N$, Joensen UN, Jensen TK, Jensen MB, Almstrup K, Olesen IA, Juul A, Andersson AM, Carlsen E, Petersen JH, Toppari J \& Skakkebaek NE 2012 Human semen quality in the new millennium: a prospective cross-sectional population-based study of 4867 men. British Medical Journal Open 2 1-13.

Kamarianos A, Karamanlis X, Goulas P, Theodosiadou E \& Smokovitis A 2003a The presence of environmental pollutants in the follicular fluid of farm animals (cattle, sheep, goats, and pigs). Reproductive Toxicology 17 185-190.

Kamarianos A, Karamanlis X, Theodosiadou E, Goulas $\mathbf{P}$ \& Smokovitis A 2003b The presence of environmental pollutants in the semen of farm animals (bull, ram, goat, and boar). Reproductive Toxicology 17 439-445.

Karoui S, Diaz C, Serrano M, Cue R, Celorrio I \& Carabano MJ 2011 Time trends, environmental factors and genetic basis of semen traits collected in Holstein bulls under commercial conditions. Animal Reproduction Science 124 28-38.

Kholkute SD \& Dukelow WR 1997 Effects of polychlorinated biphenyl (PCB) mixtures on in vitro fertilization in the mouse. Bulletin of Environmental Contamination and Toxicology 59 531-536.

Kholkute SD, Rodriguez J \& Dukelow WR 1994 Reproductive toxicity of Aroclor-1254: effects on oocyte, spermatozoa, in vitro fertilization, and embryo development in the mouse. Reproductive Toxicology 8 487-493.

Kirkegaard M, Sonne C, Dietz R, Letcher RJ, Jensen AL, Hansen SS, Jenssen BM \& Grandjean P 2011 Alterations in thyroid hormone status in Greenland sledge dogs exposed to whale blubber contaminated with organohalogen compounds. Ecotoxicology and Environmantal Safety 74 157-163.

Kuijper EA, Ket JC, Caanen MR \& Lambalk CB 2013 Reproductive hormone concentrations in pregnancy and neonates: a systematic review. Reproductive Biomedicine Online 27 33-63.

Lagos-Cabre R \& Moreno RD 2012 Contribution of environmental pollutants to male infertily: a working model of germ cell apoptosis induced by plasticizers. Biological Research 45 5-14.

Lea RG, Rhind SM, Egbowon B, Amezaga MR, Cotinot C, Loup B, Mandon-Pepin B, Fowler PA \& Sinclair KD 2010 Ovine fetal testis development is perturbed by in-utero exposure to a cocktail of chemicals contained in sewage sludge. In Society for Reproduction and Fertility, 60th Anniversary Meeting, pp. 26, Abstract 05.

Lea RG, Loup B, Mandon-Pepin B, Amezaga MR, Rhind SM, Webb R, Bennett A, Fowler PA, Cotinot C \& Sinclair KD 2011 Maternal exposure to DEHP and PCB congeners $(101+118)$ : Differential effects on male and female pituitary-gonadal axis (abstract). In 7th Copenhagen Workshop of Endocrine Disrupters.

Lenie S \& Smitz J 2009 Steroidogenesis-disrupting compounds can be effectively studied for major fertilityrelated endpoints using in vitro cultured mouse follicles. Toxicology Letters 185 143-152.

Lopez-Alonso M, Miranda M, Garcia-Partida P, Cantero F, Hernandez J \& Benedito JL 2007 Use of dogs as indicators of metal exposure in rural and urban habitats in NW Spain. Science of the Total Environment 372 668-675. 
Losa SM, Todd KL, Sullivan AW, Cao J, Mickens JA \& Patisaul HB 2011 Neonatal exposure to genistein adversely impacts the ontogeny of hypothalamic kisspeptin signaling pathways and ovarian development in the peripubertal female rat. Reproductive Toxicology 31 280-289.

Loup B, Mandon-Pepin B, Amezaga MR, Poumerol E, Kyle CE, Lea RG, Sinclair KD, Rhind SM, Fowler PA \& Cotinot C 2011 Maternal exposure to a complex mixture of environmentally-relevant chemicals during critical developmental windows differentially affects fetal ovarian follicles and ovarian transcriptome. In 6th Copenhagen Worshop on Endocrine Disruptors.

Majdič G 2010 Endocrine disrupting chemicals in domestic animals. Slovenia Veterinary Research 47 1-34.

Mandon-Pépin B, Loup B, Amezaga MR, Lea RG, Sinclair KD, Rhind SM, Fowler PA \& Cotinot C 2013 Comparison of sheep foetal ovarian development after in vivo and in vitro exposure to DEHP/MEHP, PCBs $(101+118)$ and a mixture of both. In 7th Copenhagen Workshop of Endocrine Disrupters.

Mascarenhas MN, Flaxman SR, Boerma T, Vanderpoel S \& Stevens GA 2012 National, regional, and global trends in infertility prevalence since 1990: a systematic analysis of 277 health surveys. PLoS Medicine 9 e1001356.

Mazur CS, Kenneke JF, Hess-Wilson JK \& Lipscomb JC 2010 Differences between human and rat intestinal and hepatic bisphenol A glucuronidation and the influence of alamethicin on in vitro kinetic measurements. Drug Metabolism and Disposition 38 2232-2238.

Mitchell RT, Cowan G, Morris KD, Anderson RA, Fraser HM, McKenzie KJ, Wallace WH, Kelnar CJ, Saunders PT \& Sharpe RM 2008 Germ cell differentiation in the marmoset (Callithrix jacchus) during fetal and neonatal life closely parallels that in the human. Human Reproduction 23 2755-2765.

Mohr S, Garcia-Bermejo A, Herrero L, Gomara B, Costabeber IH \& Gonzalez MJ 2014 Levels of brominated flame retardants (BFRs) in honey samples from different geographic regions. Science of the Total Environment 472 741-745.

Myllymaki S, Haavisto T, Vainio M, Toppari J \& Paranko J 2005 In vitro effects of diethylstilbestrol, genistein, 4-tert-butylphenol, and 4-tert-octylphenol on steroidogenic activity of isolated immature rat ovarian follicles. Toxicology and Applied Pharmacology 204 69-80.

O'Brien DJ, Kaneene JB \& Poppenga RH 1993 The use of mammals as sentinels for human exposure to toxic contaminants in the environment. Environmental Health Perspectives 99 351-368.

O'Shaughnessy PJ, Monteiro A, Bhattacharya S, Fraser MJ \& Fowler PA 2013 Steroidogenic enzyme expression in the human fetal liver and potential role in the endocrinology of pregnancy. Molecular Human Reproduction 19 177-187.

Pacey AA 2013 Are sperm counts declining? Or did we just change our spectacles? Asian Journal of Andrology 15 187-190.

Panseri S, Catalano A, Giorgi A, Arioli F, Procopio A,
Britti D \& Chiesa LM 2014 Occurrence of pesticide residues in Italian honey from different areas in relation to its potential contamination sources. Food Control 38 150-156.

Paul C, Rhind SM, Kyle CE, Scott H, McKinnell C \& Sharpe RM 2005 Cellular and hormonal disruption of fetal testis development in sheep reared on pasture treated with sewage sludge. Environmental Health Perspectives 113 1580-1587.

Pepling ME 2012 Follicular assembly: mechanisms of action. Reproduction 143 139-149.

Petro EM, Covaci A, Leroy JL, Dirtu AC, De Coen W \& Bols PE 2010 Occurrence of endocrine disrupting compounds in tissues and body fluids of Belgian dairy cows and its implications for the use of the cow as a model to study endocrine disruption. Science of the Total Environment 408 5423-5428.

Petro EM, Leroy JL, Van Cruchten SJ, Covaci A, Jorssen EP \& Bols PE 2012 Endocrine disruptors and female fertility: focus on (bovine) ovarian follicular physiology. Theriogenology 78 1887-1900.

Pocar P, Perazzoli F, Luciano AM \& Gandolfi F 2001 In vitro reproductive toxicity of polychlorinated biphenyls: effects on oocyte maturation and developmental competence in cattle. Molecular Reproduction and Development 58 411-416.

Pocar P, Nestler D, Risch M \& Fischer B 2005 Apoptosis in bovine cumulus-oocyte complexes after exposure to polychlorinated biphenyl mixtures during in vitro maturation. Reproduction 130 857-868.

Pocar P, Fiandanese N, Secchi C, Berrini A, Fischer B, Schmidt JS, Schaedlich K, Rhind SM, Zhang Z \& Borromeo V 2012 Effects of polychlorinated biphenyls in CD-1 mice: reproductive toxicity and intergenerational transmission. Toxicological Sciences 126 213-226.

Poulain M, Frydman N, Duquenne C, N'Tumba-Byn T, Benachi A, Habert R, Rouiller-Fabre V \& Livera G 2012 Dexamethasone induces germ cell apoptosis in the human fetal ovary. Journal of Clinical Endocrinology and Metabolism 97 E1890-1897.

Rabinowitz P, Scotch M \& Conti L 2009 Human and animal sentinels for shared health risks. Veterinaria Italiana 45 23-24.

Rhind SM, Smith A, Kyle CE, Telfer G, Martin G, Duff E \& Mayes RW 2002 Phthalate and alkyl phenol concentrations in soil following applications of inorganic fertiliser or sewage sludge to pasture and potential rates of ingestion by grazing ruminants. Journal of Environmental Monitoring 4 142-148.

Rhind SM, Kyle CE, Telfer G, Duff EI \& Smith A 2005 Alkyl phenols and diethylhexyl phthalate in tissues of sheep grazing pastures fertilized with sewage sludge or inorganic fertilizer. Environmental Health Perspectives 113 447-453.

Rhind SM, Kyle CE, Mackie C \& McDonald L 2009 Accumulation of endocrine disrupting compounds in sheep fetal and maternal liver tissue following exposure to pastures treated with sewage sludge. Journal of Environmental Monitoring 11 1469-1476. 
Rhind SM, Evans NP, Bellingham $M$, Sharpe RM, Cotinot C, Mandon-Pepin B, Loup B, Sinclair KD, Lea RG, Pocar P, Fischer B, van der Zalm E, Hart K, Schmidt JS, Amezaga MR \& Fowler PA 2010 Effects of environmental pollutants on the reproduction and welfare of ruminants. Animal 4 1227-1239.

Rhind SM, Kyle CE, Mackie C, Yates K \& Duff El 2011 Geographic variation in tissue accumulation of endocrine disrupting compounds (EDCs) in grazing sheep. Environmental Pollution 159 416-422.

Rhind SM, Kyle CE, Ruffie H, Calmettes E, Osprey M, Zhang ZL, Hamilton D \& McKenzie C 2013 Shortand long-term temporal changes in soil concentrations of selected endocrine disrupting compounds (EDCs) following single or multiple applications of sewage sludge to pastures. Environmental Pollution 181 262270.

Roa J, Navarro VM \& Tena-Sempere M 2011 Kisspeptins in reproductive biology: consensus knowledge and recent developments. Biology of Reproduction 85 650-660.

Rolland M, Le Moal J, Wagner V, Royere D \& De Mouzon J 2013 Decline in semen concentration and morphology in a sample of 26,609 men close to general population between 1989 and 2005 in France. Human Reproduction 28 462-470.

Rostad B, Schmidt L, Sundby J \& Schei B 2013 Has fertility declined from mid-1990s to mid-2000s? Acta Obstetrica et Gynecologica Scandinavica 92 1284-1289.

Rozati R, Reddy PP, Reddanna P \& Mujtaba R 2002 Role of environmental estrogens in the deterioration of male factor fertility. Fertility and Sterility 78 1187-1194.

Sarraj MA \& Drummond AE 2012 Mammalian foetal ovarian development: consequences for health and disease. Reproduction 143 151-163.

Sathananthan AH, Selvaraj K \& Trounson A 2000 Fine structure of human oogonia in the foetal ovary. Molecular and Cellular Endocrinology 161 3-8.

Savabieasfahani M, Kannan K, Astapova O, Evans NP \& Padmanabhan V 2006 Developmental programming: differential effects of prenatal exposure to bisphenol-A or methoxychlor on reproductive function. Endocrinology 147 5956-5966.

Sawyer HR, Smith P, Heath DA, Juengel JL, Wakefield SJ \& McNatty KP 2002 Formation of ovarian follicles during fetal development in sheep. Biology of Reproduction 66 1134-1150.

Schilling RJ \& Stehr-Green PA 1987 Health effects in family pets and 2,3,7,8-TCDD contamination in Missouri: a look at potential animal sentinels. Archives of Environmental Health 42 137-139.

Schilling RJ, Steele GK, Harris AE, Donahue JF \& Ing RT 1988 Canine serum levels of polychlorinated biphenyls (PCBs): a pilot study to evaluate the use of animal sentinels in environmental health. Archives of Environmental Health 43 218-221.

Schmidt PL 2009 Companion animals as sentinels for public health. Veterinary Clinics of North America Small Animal Practice 39 241-250.

Setchell BP 1997 Sperm counts in semen of farm animals 1932-1995. International Journal of Andrology 20 209-214.
Skakkebaek NE, Rajpert-De Meyts E \& Main KM 2001 Testicular dysgenesis syndrome: an increasingly common developmental disorder with environmental aspects. Human Reproduction 16 972-978.

Smith KC, Brown PJ \& Barr FJ 2012 A survey of congenital reproductive abnormalities in rams in abattoirs in South west England. Reproduction in Domestic Animals 47 740-745.

Snoj T, Kobal S, Premrov Bajuk B, Zuzek MC, CebuljKadunc N \& Majdic G 2013 Retrospective study of bull semen quality - possible correlation with pesticide use? Acta Veterinaria Hungarica 61 495-504.

Sonne C, Leifsson PS, Dietz R, Born EW, Letcher RJ, Hyldstrup L, Riget FF, Kirkegaard M \& Muir DC 2006 Xenoendocrine pollutants may reduce size of sexual organs in East Greenland polar bears (Ursus maritimus). Environmental Science and Technology 40 5668-5674.

Spiller CM, Bowles J \& Koopman P 2012 Regulation of germ cell meiosis in the fetal ovary. International Journal of Developmental Biology 56 779-787.

Stevens JL, Northcott GL, Stern GA, Tomy GT \& Jones KC 2003 PAHs, PCBs, PCNs, organochlorine pesticides, synthetic musks, and polychlorinated n-alkanes in U.K. sewage sludge: survey results and implications. Environmental Science and Technology 37 462-467.

Swan SH, Elkin EP \& Fenster L 2000 The question of declining sperm density revisited: an analysis of 101 studies published 1934-1996. Environmental Health Perspectives 108 961-966.

Takeuchi T, D'Itri FM, Fischer PV, Annett CS \& Okabe M 1977 The outbreak of Minamata disease (methyl mercury poisoning) in cats on Northwestern Ontario reserves. Environmental Research 13 215-228.

Tang WY, Newbold R, Mardilovich K, Jefferson W, Cheng RY, Medvedovic M \& Ho SM 2008 Persistent hypomethylation in the promoter of nucleosomal binding protein 1 (Nsbp1) correlates with overexpression of Nsbp1 in mouse uteri neonatally exposed to diethylstilbestrol or genistein. Endocrinology 149 5922-5931.

Tena-Sempere M 2010 Kisspeptin/GPR54 system as potential target for endocrine disruption of reproductive development and function. International Journal of Andrology 33 360-368.

Tornkvist A, Glynn A, Aune M, Darnerud PO \& Ankarberg EH 2011 PCDD/F, PCB, PBDE, HBCD and chlorinated pesticides in a Swedish market basket from 2005-levels and dietary intake estimations. Chemosphere 83 193199.

van der Schalie WH, Gardner HS, Jr., Bantle JA, De Rosa CT, Finch RA, Reif JS, Reuter RH, Backer LC, Burger J, Folmar LC \& Stokes WS 1999 Animals as sentinels of human health hazards of environmental chemicals. Environmental Health Perspectives 107 309-315.

Veiga-Lopez A, Luense LJ, Christenson LK \& Padmanabhan V 2013 Developmental programming: gestational bisphenol-A treatment alters trajectory of fetal ovarian gene expression. Endocrinology 154 1873-1884.

Verreault J, Dietz R, Sonne C, Gebbink WA, Shahmiri S \& Letcher RJ 2008 Comparative fate of organohalogen contaminants in two top carnivores in Greenland: 
captive sledge dogs and wild polar bears. Comparative Biochemistry and Physiology Part C: Toxicology \& Pharmacology 147 306-315.

Voorspoels S, Covaci A, Neels H \& Schepens P 2007 Dietary PBDE intake: a market-basket study in Belgium. Environment International 33 93-97.

Wahl RL \& Reif JS 2009 Temporal trends in bull semen quality: a comparative model for human health? Environmental Research 109 273-280.
Welsh M, Saunders PT, Fisken M, Scott HM, Hutchison GR, Smith LB \& Sharpe RM 2008 Identification in rats of a programming window for reproductive tract masculinization, disruption of which leads to hypospadias and cryptorchidism. Journal of Clinical Investigation 118 1479-1490.

Zhang YH, Zheng LX \& Chen BH 2006 Phthalate exposure and human semen quality in Shanghai: a cross-sectional study. Biomedical and Environmental Sciences 19 205-209. 
